\title{
Humanistic Poets And Classical Philosophy
}

\author{
Wilhelm Blum \\ (München, drw.blum@gmx.de)
}

\section{Introduction}

During the so-called Hellenism (the centuries from ca. 300 to ca. 30 before Christ) there were four philosophical schools:

- Plato, the Platonics and the Neoplatonics like Plotinus;

- Aristotle and his followers, the Peripatetics;

- the Stoics;

- the Epicureans ${ }^{1}$

These four schools had followers and adversaries, especially the Stoics and the Epicureans were hostile to each other. Whereas these two schools disappeared in the fourth century after Christ at the latest - the poem Le Stoicien king Frederic the Great wrote on $15^{\text {th }}$ November 1761 is a real exception! - the thoughts of Plato and Aristotle were still alive and influenced many thinkers, especially the Christians like Augustine or Thomas Aquinas. During the $15^{\text {th }}$ century there were frequent discussions about Plato and Aristotle, especially in Italy - we may mention the great discussions during the time of the Ecumenical Council of Ferrara-Florence in 1438 and 1439 -, and the statement of Alfred North Whitehead from $20^{\text {th }}$ century is well known: the whole philosophical tradition of the world seems to be nothing else "but some footnotes to Plato" (Whitehead 1967, 63). Of course, each of the four schools mentioned above generated followers (and adversaries too!), but Plato and Aristotle may be called the teachers of Europe and the whole world, from their times of the fourth century before Christ to our times and beyond.

We will demonstrate these facts by a view into two, only two, poems of $16^{\text {th }}$ and $17^{\text {th }}$ centuries, one by Thomas More (1478 - 1535), the humanist and statesman, the other by the German Jesuit Jacob Balde (1604 - 1668). Our interpretation of these two poems will show how deeply the ancient philosophers influenced these poets and their times; those two poems will serve us as examples for the great influence of ancient thinking. Without Plato, Aristotle, the Stoics and the Epicureans (and without the Presocratics like Heraclitus and Parmenides) we are not able to explain modern literature or philosophy: this statement concerns Johann Wolfgang von Goethe (Grumach

1 The cynics "passed over into Stoicism" as Bertrand Russell pointed out (Russell 1961,242 ) and the Skeptics seem not to have founded a real philosophical school. 
1949) as well as Fyodor Dostoyevsky (Lauth 1950), Giovanni Pascoli as well as August Strindberg, Karl Marx, Martin Heidegger or Giorgio Agamben and many others. Without the antiquity no explanation of modern thinking is possible, there will be no understanding of modern philosophical thought without ancient writers and philosophers.

\section{The Epigram 119 of Thomas More "On the Vanity of Human Life"}

In hvivs vitae vanitatem

Damnati ac morituri in terrae claudimur omnes

Carcere, in hoc mortem carcere nemo fugit.

Carceris in multas describitur area partes,

Inque alijs alij partibus aedificant.

Non aliter quam de regno de carcere certant.

In caeco cupidus carcere condit opes,

Carcere obambulat hic uagus, hic uincitur in antro.

Hic seruit, regit hic, hic canit, ille gemit.

Iam quoque dum carcer non tanquam carcer amatur,

Hinc alijs alij mortibus extrahimur.

(C.H. Miller et al. 1984, 166 et 168) ${ }^{2}$

As the English language is not suitable for hexametric or pentametric verses I give here a translation in German, in my mother tongue:

Sterben werden wir alle, verdammt sind wir: Irdisch Gefängnis Schließt uns ein, es entkommt niemand im Kerker dem Tod.

Zahlreich und groß sind die Plätze des Kerkers, so sind sie beschrieben:

Einer baut hier, und dort richtet der andre sich ein.

Und es kämpfet ein Jeder, als gält' es im Kerker zu herrschen.

In diesem finstern Verlies sammelt der Habsücht'ge Geld,

der läuft frei durch die Höhle, der andre wird in ihr gefesselt;

der ist Sklave, der Herr, der singt voll Freude, der klagt.

\footnotetext{
2 "We are all shut up in the prison of this world under sentence of death. In this prison none escapes death. The land within the prison is divided into many sections, and men build their dwellings in different sections. As if the prison were a kingdom, the inmates struggle for position. The avaricious man hoards up wealth within the dark prison. One man wanders freely in the prison, another lies shackled in his cave; this man serves, that one rules; this one sings, that one groans. And then, while we are escorted out of it, one way or another, y death" (C.H. Miller et al., 167 et 169).
} 
Und da wir dieses Gefängnis noch lieben, als wäre es gar keines, schleppt uns der Tod von hier weg, jeden auf eigene Art.

Or for the two last verses:

Da von uns dieses Gefängnis, weil Kerker, niemals geliebt wird, schleppt uns der Tod von hier weg, jeden auf eigene Art.

\subsection{Notes to the text and the translation}

\subsubsection{Damnati:}

The translation "we are all shut up" seems too simple or too polite. I would propose "we are all damned" ("verdammt sind wir alle") because we are thrown out of paradise, we live under the bad condition of original sin.

\subsubsection{Morituri:}

For the participle of the future in an absolute manner compare e.g. Horace, Odes I, 28, 6 and II 3,4 or St. Augustine, Sermon 302 (Migne, Patrologia Latina 38 , p. 1387): In quam magno timore sunt homines, ne moriantur morituri = How great is man's fear to die, although he is determined to death by nature.

\subsubsection{Carcer:}

The word "prison" or "jail" is used eight times whereas "cave" or "den" appears only once. But the idea being the same we may look at these words just as synonyms.

\subsubsection{Aliis alii:}

This formula appears twice. More focuses on the human individuals, nobody has the same fate as his fellow-man, everybody has his own proper fate.

\subsubsection{De regno:}

The word of "kingdom" is used as the symbol of power, rule or government, just as More knew it from England or France of the sixteenth century.

\subsubsection{In caeco carcere:}

"Caecus" (blind) is used here in a passive sense, compare "caeca caligine" (Vergil, Aen. VI 203) or "caeco carcere" (ibidem, 734). More seems to have wanted to imitate the speech of Anchises in which he explains human life to his son Aeneas, so we quote the two verses which are very similar to More's (Vergil, Aen. VI, 733-734):

Hinc metuunt cupiuntque, dolent gaudentque, neque auras dispiciunt clausae tenebris et carcere caeco. 


\subsection{7: Vincitur:}

The hexameter proves that we have to read "vincítur" - the second "i" being a long syllable (so the translation "shackled" is very good).

\subsubsection{Iam quoque dum carcer... :}

There are two possibilities of translation of the two last verses:

- The prison is loved very much (by men) just as if it were not a prison, nevertheless we must be extracted by death and everybody has to experience his own death.

- The prison being a real prison cannot be loved at all, so we must be extracted by death and everybody has to experience his own death.

These two translations are opposite to each other, but both are grammatically possible. Most translators however tend to the first solution, see the English translation above. But we compare the Italian translation: "[...] da questo carcere, che amiamo come se tale non fosse, veniamo tratti fuori [...]" (Firpo et Paglialuga 1994, 237). It is important to see the two possibilities Thomas More trifles with - I am sure he enjoyed both -, but the first translation seems to be the best one.

\subsubsection{Extrahimur:}

We must take notice of the passive voice by which More teaches us: We cannot get out of this prison by ourselves, but we will be extracted. Man is passive, man can do nothing because the active part is God, nobody else - God is the extractor. So death is the line of paradise or punishment in hell, both being endless, death is line or gate to eternity, death is the line by which man - i.e. the creation - will see his God, the Creator.

\subsection{Sources and patterns}

First of all, we mention as a source Lucian's Charon and his Dialogues of the dead. Surely More knew these texts of the great mocker from the second century after Christ although he had not translated them into Latin. For instance, in this epigram 119 we may discover reminiscences of Polycrates, the king of Samos, in chapter fourteen of Lucian's Charon (Iacobitz 1909, 205-222 et 136-190; Schirnding 1977). Or alternatively we may quote Charon's sentences in chapter twenty: 
Oh ye vain people, why do you exert yourselves for these worthless things? Stop this exerting. You will not live for eternal times, nothing [...] is eternal and nobody can take those things with himself in the moment of his death (Jacobitz 1909, 125).

On the contemporary, everybody is forced to get out of life as a naked man. To be sure, these are commonplaces we read with many other authors, but for Thomas More, Lucian is an important literary source. The second source is the Sicilian philosopher Empedocles (5th century BC) with his special description of the world. According to his presocratic standing, our world is a "joyless place", "poor mankind depends on fate", and "mankind came into being only from quarrels and sighs". Empedocles is the first to devise the metaphor of the cave for our world and Plato will complete this idea in his famous simile of the cave or the den.

Before mentioning this Platonic simile we ought to know Plato's theory in the dialogue Phaedo:

We do not perceive that we live in the hollows, but we think we live on the upper surface of the earth [...], we dwell in a hollow of the earth and think we dwell on its upper surface (109 c, trans. by H. North Fowler).

So the world would be nothing else but a cave or a prison - both words appear in the Phaedo! -, and we have to leave the world, "for the prize is fair and the hope is great" (ibid.).

Of course the great model for More is the simile of the cave Plato gave in the beginning of the seventh book of his Republic. There is a cave whose inmates are chained (shackled): That is the first step of this simile. The further steps - liberation of these chains, ascent out of the cave up to the truth which is the sun, descent into the cave and death of the truth's prophet, murdered by the inmates of the cave - need not be mentioned here. But we may note that with More, just as with Plato (Republic VII, $616 \mathrm{c}$-d) there are some honours, some praises and also some rules within the cave - in this point More visibly follows Plato. More uses the simile of the cave in order to interpret the world - doing so he follows Plato a second time. We have to add an important fact: More not only follows Plato in his epigram 119, but in other works too, for instance in the Four Last Thynges, the Dialogue of Comfort against Tribulation (McLean 2011, 175 ) or in the Epigram 75 whose aim is shown by the title: Vita ipsa cursus ad mortem est.

\subsection{The ethics of the Epigram 119}

Nobody can escape from death, everybody is mortal, so we have to prepare ourselves for the death because death is the sole fact of our future which is certain. Nevertheless many people neglecting this fact arrange themselves for a 
life on this earth as if they lived here eternally: there are many places to do so (line 3) and so many people are constructing houses or monuments (line 4) not being aware that their life will end soon. Two cardinal sins are named here, the thirst for power (line 5) and avarice.

Speaking of these two sins More surely had in mind the doctrine of the Seven Cardinal Sins formulated by the Ancient Fathers of the Church ${ }^{3}$. These are:

- Superbia: pride or haughtiness

- Avaritia: avarice

- Luxuria: unchastity (not: prodigality)

- Invidia: envy or grudge

- Gula: gluttony

- Ira: anger

- Acedia: sorrow, indignation of soul, emptiness of soul (perhaps not translatable explicitly into a modern language)

More called only the two most important sins, so every reader will understand that he intends to speak of the old Christian doctrine of the Cardinal Sins: We must avoid these sins and we have to resist them: such is More's instruction in the lines 5 and 6 of this poem. In line 7 More treats of single destinies: One man seems to be free although he is in prison, another seems himself shackled and feels that his room is nothing else but a cave. There are two, only two, examples of behaving in the world, (seeming) freedom and actual prison. It must be noticed that More exchanges the simile of the cave: Whereas with Plato there is the chained man in the first step, and this chained man, in a second step, will be freed from his chains, More shows the free man first and the prisoner thereafter. And we remark a very Platonic detail in line 8: More thinks in ways of politics showing the first a poor slave and his fellow a king. But what is really Morean in the reference to jubilation and suffering: both are expressions of human life and both are, together with love and hate, the inner essence of human life.

We must prepare ourselves for death, I repeat interpreting the lines 9 and 10, we have contempt of this world being a prison, we must try to get out of this world. So we follow Plato who often taught the eternal life of the human soul after death, so we follow Plotinus "flight of the Alone to the Alone" (Enneads VI 9,11). We also follow the entire Platonic tradition according to which "true philosophers practice dying" (Phaedo 67 e), just as Cicero teaches: "tota philosophorum vita commentatio mortis est" (Tusculanae Disputationes I $30,74)^{4}$ whereas the Stoic Seneca does not hesitate to proclaim: during our

3 The first to write about these Cardinal Sins was Evagrius Ponticus (ca. 345-399), the first intellectual monk (see his Lógos Praktikós, ch. 6). In the Latin West we find this doctrine with John Cassian and especially with Pope Gregory I the Great.

${ }^{4}$ Cicero follows Plato, of course, esp. Phaedo 80 e. 
whole life we must learn how to live - "Tota vita discendum est mori" (De brevitate vitae 7,3 ). Our life consists in learning to die and how to die: that is the device taught by medieval monks: "Optima philosophia contemplatio mortis!"5

Now the last word of this epigram is "extrahimur". I already pointed out the passive voice: We do not go away by our own decision, but we are extracted by God Himself, who is the active part of life and death. At this point we meet the Christian Stoic: Thomas More knows very well how to combine Christian faith with Stoic ethics. Christianity and Stoicism are not contrary, but Stoic thought is completed by Christian thinking. That is the line More follows and in this concept he differs from Jacob Balde ${ }^{6}$, whose poem we will interpret now.

\title{
3. Jacob Balde: Lyrica III, 12
}

\author{
Auctor a celeberrima secta Stoicorum desciscit \\ Quid mihi vobiscum est, stoae foetentis alumni \\ Deucalione sati? \\ Mobile lignorum genus et viventia saxa, \\ Quae tamen Ogygiam \\ Amphion nullus cithara traxisset ad urbem \\ Pondere fixa suo. \\ Iam tandem deprensa mihi fraus omnis et error: \\ Pene ligatus eram; \\ Stupea sed valido disrupi vincula nervo \\ Ceu putrefacta situ. \\ Estis, io, rigidi cultores estis honesti, \\ Usque severa tribus. \\ Non turgent oculi lacrymis, non gaudia risu; \\ Non tumet igne iecur, \\ Nullaque sedatum tempestas pectus inundat: \\ Omnia pace vigent. \\ Credite Pisones: at non ego; credite verpi, \\ Gens inimica Deo: \\ Credere me tristis vetat experientia rerum \\ Nec sinit esse rudem. \\ Auditis? Quorum virtus olet horrida caepas
}

\footnotetext{
${ }^{5}$ For instance you may read this device on the walls of the former Charterhouse of Padula in Lucania. We quote this Carthusian device because Thomas More admired the Carthusians. For almost four years he had lived with the monks in the London Charterhouse in Order to prove his life, yet we know he decided not to enter the Carthusian Order but to live as a layman in the world.

${ }^{6}$ Jacob Balde, born 1604 in Alsace, entered the Jesuit Order in 1624. He was Professor of Classics in the Jesuit Colleges of Munich, Innsbruck, and Ingolstadt and then preacher at Landshut, Amberg and finally Neuburg on the Danube, where he died on $9^{\text {th }}$ August 1668.
} 
Totaque vita sedet:

Qualis in Adriacis Venetum secura phaselus,

Et mea ludet aquis.

Decurrat placidis innubila moribus aetas

Temperiemque ferat,

Non suspecta metu, non importuna tumore,

Non odiosa minis.

Tempus erit, laetus risum cum poscet amicus:

Splene feremus opem.

Tempus erit flendi: veris manabit in uda

Fletibus ora dolor.

Denique verus homo, non truncus inutilis agri,

Nec lapis esse volo.

(Wehrli 1963, 54 et 56)

\subsection{Notes to the text}

\subsubsection{Line 1:}

Balde's reproach that the Stoics seem to stink is very strange, we may interpret it which the line 21: The Stoics stink of onions.

\subsubsection{Line 2:}

Deucalion, the "Greek Noah", is a son of Prometheus (and his wife Pyrrha, a daughter of Epimetheus). After the Great Flood this couple had to throw stones backwards over their shoulders: his stones became men, hers women (Apollodorus I, 46-48; Hyginus, Fabulae 153; Ovid, Metamorphoses I 318-415).

\subsubsection{Line 3:}

Balde thinks the Stoics are nothing else but stones (see also lines 2 and 38).

\subsubsection{Line 5:}

Amphion is said to have evoked on his lyre such a brilliant music that even the stones began to move (Apollodorus III, 44; Hyginus, Fabulae 9).

3.1.5 Line 8 - 10:

"I had just come near to being chained" by the Stoics, but I knew very well how to break these chains (cp. Balde, Lyrica III 16)

\subsubsection{Line 11:}

Balde trifles with the Latin language in a wonderful manner as there are three possible translations:

- "Ye Stoics, you are rigid adorers of the virtue"

- "Ye Stoics, you are adorers of the rigid virtue"

- "ye Stoics, you are honourable adorers of the rigidity" 
We should decide in favour of the first translation although we know that the others are not only possible grammatically, but rich in meaning; to be sure, the third translation does not follow Balde's intention: in this verse we see Balde quoting from memory the Roman author Lucanus (39 - 65). In his Ten Books of Civil War (Lucanus II 389) he is praising Cato the Younger (95 - 46 B.C.), the Stoic, as iustitiae cultor rigidi servitor honesti.

\subsubsection{Line 16:}

Balde does not mean the positive word, but the negative one: cemetery's peace.

\subsubsection{Line 17:}

Gaius Calpurnius Piso was the leading conspirator against Emperor Nero in 65 A.C. Balde alludes to the Stoic opposition to this Emperor under Thrasea Paetus, but he mentions the Pisones because their family is better known (for Piso's suicide see Tacitus, Annals XV 48-59).

"Verpi" has just the same meaning as "curti" in the Satires of Horace: "circumcised" (I 9, 70). So this word is a synonym for the people of the Jews.

\subsubsection{Line 18:}

The Jews are named "God's enemies" - we must not forget that Balde is a Jesuit of the $17^{\text {th }}$ century.

\subsubsection{Line 22:}

"Life is sitting around in idleness only" (For this use of the Latin word "sedere" see: Horace, Epistles I 17, 37; Livius III, 68,8: "sedemus desides domi").

\subsubsection{Line 27:}

Balde seems to trifle with the differences between Germany (or even Bavaria) as a rough territory and lovely Italy (which he had never seen during his life).

\subsubsection{Line 30:}

"Spleen" being a Greek word is a foreign one in Latin - it means "milt". The English word "spleen" is derived from that Greek-Latin word.

\subsubsection{Line 37:}

One of the central reproaches: According to Balde the Stoics do not seem to be real men having pleasure and harms, they resemble stones which are free from any passions.

\subsection{The ethics in Balde's Lyrica III, 12}


Of course, in this poem we do not have a system of Balde's ethics but only a little part of Balde's perception of ethics. We know that he appreciated the Stoics (see for instance Lyrica IV, 30) because their ethics is quite near to that of the Christians. However, we have a fine example of the really long effect ancient philosophy had on later thinking: the Stoic philosophy is an error (line 7), and the Stoics themselves are like lifeless stones and wood, there are no feelings or sensations, only severity and obligations. The Stoics are to be defined by haughtiness and pride (line 24), and every Christian knows - at least by reading the City of God, the central work of the political philosophy of St. Augustine - that this is the sin of superbia. ${ }^{7}$ So Balde is summarizing the three Stoic vices in the lines 31-32: fear, haughtiness, and hate. Balde also confesses (line 19) his own sorrowful experience he has had in the Munich sect of the Stoics - his life was nothing else but sorrow and grief (cp. Lyrica IV 29-31, 33; Westermayer 1998, 96).

In this poem we see some allusions to the Epicurean ethics too. For instance, in the lines 27 or 33-38 we recognize the Epicurean joyful instead of the cosmopolitical view of the Stoics, we find out the counsel to live in retirement (or concealment) 8 . We find the watchword too: "Sustine et abstine" (for the Greek original: Aulus, Gellius, Attic Nights XVII 19,6), the contrary of this is the celebrated call of Horace: "carpe diem" (Odes I 11, 8).

Thus we observe: In this little poem of Jacob Balde there are both Stoic and Epicurean reminiscences, the ancient philosophers are the source of Balde's thought.

\section{Summary}

We tried to show the largest possible influence of ancient philosophy on other times by interpreting two - only two! - poems of the $16^{\text {th }}$ and $17^{\text {th }}$ centuries. These two poems taught us the influence of both Plato and Aristotle and of both Stoicism and Epicureism. We know that this influence is valid for all times, and we are sure we could prove this fact by innumerable literary works. To sum up: Platonism had called forth Neoplatonism, Aristotle had called the Peripatetics; we know St. Augustine as the Christian follower of Plato and Thomas Aquinas as the Christian follower of Aristotle (meaning Aristotle he only speaks of the „philosopher", just as did the Arabs).

7 The fellow-Jesuit Jacob Bidermann (1578 - 1639) has written and performed at Munich in 1609 the play "Cenodoxus", the story of the famous Doctor of Paris who will be damned after death by Jesus Christ because of his rigid haughtiness. The legend says this Doctor has given an incentive to Saint Bruno to found the monastic order of the Carthusians in 1084. Thrice the dead Doctor is said to have spoken out of his coffin: accusatus - iudicatus - condemnatus; he is damned because of superbia (hybris), his foolish pride.

8 The famous láthe biósas - Ovid, Tristia III 4,25: „[...] bene qui latuit bene vixit [...] “. 
During the $15^{\text {th }}$ century in Italy there was a great conflict between those who followed Plato and those who preferred to follow Aristotle - in Florence there was founded the Platonic Academy in 1459 -, Plato's doctrine of separation (chorismós) and unity (that is Plato's dialectics) is represented by both Nicholas of Cusa (1401 - 1464) and G.W.F. Hegel (1770 - 1831).

In our $21^{\text {st }}$ century there is nothing which could be named new: We too know the four ancient philosophical schools and we will never forget their great influence and their everlasting importance.

\section{References}

Grumach, E. (ed.) 1949. Goethe und die Antike. Eine Sammlung. Berlin Potsdam: De Gruyter.

Kranz, W. (ed.) 1974. Die Fragmente der Vorsokratiker. Griechisch und Deutsch von H. Diels. Berlin: Weidmann.

Lauth, R. 1950. Die Philosophie Dostojewskis. München: Piper.

McLean, S. 2011. “Thomas More's Latin Epigrams Translated Anew”. Moreana 48, No. 185-186, Issue 3-4: 172-183.

Miller, C.H. et al. (ed.) 1984. The Complete Works of St. Thomas More. Vol. 3, Part Two. New Haven - London: Yale Univ. Press

Müller, S. 1985. Jacobus Balde und die Stoa (Typewritten: "Zulassungsarbeit"). München (available in the Institute of Classical Philology of Munich University; signature: neolat. 446).

Firpo, L. 1994. Thomas More: Tutti gli epigrammi. Translated by L. Firpo, L. Paglialuga. Milano - Torino: Edizioni San Paolo.

Russell, B. 1961. History of Western Philosophy. London: Reset.

Schirnding v., A. 1977. Lukian: Charon oder die Betrachtung der Welt. München: Deutscher Taschenbuch Verlag.

Thompson, C.R. 1974. The Complete Works of St. Thomas More. Vol. 3, Part One. New Haven - London: Yale Univ. Press.

Wehrli, M. 1963. Jacob Balde: Dichtungen. Lateinisch und Deutsch von M. Wehrli. Köln - Olten: Verlag Jakob Hegner.

Westermayer, G. 1998 (ed. by H. Pörnbacher \& W. Stroh). Jacobus Balde (16041668), sein Leben und seine Werke. Amsterdam - Maarssen: APA Holland Univ. Press.

Whitehead, A. N. 1967. Process and Reality, New York: The Free Press. 


\title{
Wilhelm Blum
}

(Munich,drw.blum@gmx.de)

\section{Humanistic Poets And Classical Philosophy}

\begin{abstract}
The aim of the article is to show that the so-called "philosophia perennis" is valid for our modern times too. Four philosophical schools of the Hellenistic times remain influential for the following centuries: Plato and Neoplatonism, Aristotle and the Peripatetics, the Stoics and the Epicureans. We are interpreting two, only two, poems from Thomas More and Jacob Balde, and so we see the greatest possible influence of all these four ancient philosophical schools.
\end{abstract}

Keywords: Thomas More, Jacob Balde, Ancient Ethics, Stoicism, Neoplatonism, Humanism, Renaissance Philosophy

Ethics in Progress (ISSN 2084-9257). Vol. 7 (2016). No. 2, Art. \#6, pp. 82-94.

Creative Commons BY-SA 3.0

Doi: 10.14746/eip.2016.2.8 